\title{
The Functional Alterations of The Avian Salt Gland Subsequent to Osmotic Stress
}

Zeinab M. El-Gohary, Fawkeia I. El-Sayad, Hanaa Ali Hassan and Aya Mohammed Magdy Hamoda

Zoology Dept., Faculty of Science, Mansoura University, Egypt

\begin{abstract}
:
Background: Many terrestrial non-marine birds have functional salt glands. Their salt glands are usually quiescent. However, such glands show remarkable levels of phenotypic plasticity both morphological and physiological as a consequence of drinking saline water.

Objective: The current investigation was conducted to reveal in more detail the different functional alterations of the duck's salt glands subsequent to high salt osmotic stress.

Material and methods: The selected avian species were the domestic female (Anas platyrhyncha) and the wild migratory (Anas clypeata) ducks. Two groups of domestic and one group of wild ducks were considered in the present study, each of which included nine adult ducks. The high salt osmotic stress was induced by replacing drinking tap water of the domestic ducks with $1 \%$ sodium chloride solution for two consecutive weeks. The measured parameters were included some electrolytes in both serum and glandular tissue. Also, Na-KATPase activity and aldosterone concentrations were considered.

Results: The present study elucidated that serum sodium, potassium, chloride and uric acid of the wild migratory ducks were markedly higher than those of both salt-stressed and control ducks. In addition, serum aldosterone concentration of the wild migratory ducks was distinctly higher in comparison with those of the control and the salt-stressed ones. Moreover, salt gland tissue homogenate electrolyte contents followed the same pattern as those of serum electrolyte concentrations. In contrast, the activity of Na-K-ATPase of the salt gland homogenates was higher in the salt-stressed ducks in comparison to both wild migratory and control groups.

Conclusion: From the above mentioned results, it was concluded that the peculiar functional status of the salt gland of the experimentally salt-stressed ducks comparing to the control may be presented as an adaptive features to satisfy its special demands to eliminate the remarkable increased levels of sodium chloride load effectively.
\end{abstract}

Key words: Ducks, Salt gland, Osmotic stress, Electrolytes, Na-K-ATPase

\section{Introduction:}

The osmotic regulation in vertebrates is largely the result of controlled movements of water and solutes across epithelial membranes. In mammals, the kidneys play the critical role in this process. On the other hand, in birds the kidneys, intestine, and in some species, the supraorbital salt glands all play important roles in osmoregulation. Although the presence of the supraorbital salt gland in marine birds has long been known to ornithologists, however, its excretory function was not discovered until 1957-1958 when Knut Schmidt-Nielsen and co-workers found that these glands in the herring gulls (Larus argentatus) excreted sodium chloride $(\mathrm{NaCl})$ in concentrated solution (1). Such glands enable marine birds to drink brackish or full seawater, secrete salt and conserve osmotically free water $(2,3)$.
Because salt gland provides an elegant model of the mechanisms involved in active transport of sodium and chloride, the physiological efficiency of the gland has been exclusively investigated $(4,5,6)$. The salt gland removes sodium chloride from the blood far more efficiently than does the avian kidney and excretes it as brine through a duct into the nasal cavity and is eliminated in liquid form through the nostrils, often accompanied by vigorous shaking of the bird's head or forced "sneezing"(7). The concentration of the secreted fluid is always high, several times as high as the maximum urine concentration in birds (8).

All marine birds have salt glands that, together with the kidneys, maintain body fluid homeostasis, despite the excess sodium chloride $(\mathrm{NaCl})$ they ingest. They 
have similar total body water, but twice the daily water flux of birds that lack salt glands ( 9). Among species that produce highly concentrated salt gland secretion (SGS), the salinity of the drinking water has no effect on drinking rate (10). Such birds become dehydrated only when they drink water more concentrated than their SGS (10).

Drinking sea water and feeding on saline marine food put physiological stress on marine birds to reduce the salt load and to eliminate excess electrolytes. Birds inhabit freshwater ponds possess significantly small or inactive salt glands while seabirds who have limited or no excess to freshwater are equipped with well developed specialized salt glands $(11,12)$.

Even in birds, that had never been exposed to salt water, salt gland secretion can be elicited by salt loading. Mallard ducks, Anas platyrhynchos, that have never experienced sea water can produce nasal gland secretions containing 35 mOsmol. $\mathrm{Kg}^{-1}$ when challenged with an infusion of saline water. However, this concentration is only $20 \%$ of the concentration achieved by ducks that have been chronically adapted to sea water (13). An increase in $\mathrm{Na}+, \mathrm{K}+$-ATPase content and surface area of the basolateral plasma membrane of the principal cell of the quail (14), duck (15) and geese (16) salt glands has been recorded during salt-water adaptation.

It has been well established that many species of ducks switch seasonally between freshwater and saline habitats. When the drinking water of these species is changed from freshwater to saline, their salt gland hypertrophy, enhancing their capacity to excrete salt (17) and the fractional reabsorption of sodium is reduced $(17,18)$. Whether these responses occur in other terrestrial birds with salt glands did not reported for domestic ducks (Anas platyrhyncha).

\section{Aim of the work:}

The purpose of this investigation was to determine whether or not the supraorbital salt glands of the female domestic ducks exhibit functional alterations subsequent to high salt manipulation (drinking 1\% $\mathrm{NaCl}$ solution). The migratory wild northern shovelers (Anas clypeata) inhabit brackish water in the Lake Manzala were considered in this investigation to be compared with those experimentally osmotic-stressed domestic ducks (Anas platyrhyncha).

\section{Material and methods:}

\section{I- The selected birds}

The selected birds of the current investigation included two different avian species which inhabit different habitats; female domestic ducks (Anas platyrhyncha) and the female wild migratory ducks (Anas clypeata). The domestic ducks inhabit lakes, streams and nearby grassland and farm crops. The domestic duck's diet consists of plant material obtained by grazing or dabbling in shallow water. On the other hand, the wild migratory duck feeds on little aquatic animals, mollusks and plankton captured in shallow water or filtrated from the layer close to the surface of the brackish water of the Manzala lake. Both studied species are belong to the family Anatidae or dabbling ducks.

The domestic ducks were bought from a local duck farm while the wild migratory ducks were hunted from the lake Manzala area and transported immediately to the laboratory for subsequent experimental investigation. The experimental domestic birds were housed in special avian farm under a cycle of $12 \mathrm{~h}$ light $-12 \mathrm{~h}$ dark and fed commercial duck grower food with drinking water ad libitum for a further three days before they were used for the experiments.

The investigated groups of the present study included control female domestic ducks (Anas platyrhyncha), salt-stressed female domestic ducks (Anas platyrhyncha) and wild migratory female ducks (Anas clypeata), each of which contained nine adult healthy ducks.

The treated group of the domestic ducks (the salt-stressed group) was given $1 \%$ $\mathrm{NaCl}$ solution to drink for two consecutive weeks. While the control ducks were maintained exclusively on tap water for the same period. The two groups of the domestic ducks were weighed before the beginning, after the first week and at the end of the experiment to detect the ability of the salt-stressed birds to maintain body 
weight while drinking salt water as a general index of tolerance to saline conditions.

At the end of the experiment, all the studied birds were sacrificed by a sharp knife to collect blood samples, after which they were dissected to remove out the right and left salt glands from the eye socket after pulling out the eye balls. Since the structure of the medial and lateral segments of the salt glands of the avian species are identical, only the medial segments were considered in the present study. The glands were immediately cleaned by filter paper.

\section{I1- Analytical Techniques}

1-Collection of the blood serum samples

The blood samples were collected in clean centrifuge tubes. The samples were centrifuged immediately for ten minutes at 3000 r.p.m. The serum samples were collected, labeled and stored at $-20^{\circ} \mathrm{C}$ for later biochemical analysis.

\section{2- Determination of electrolyte concentrations and contents}

Serum and the homogenate of the right medial segments of the salt gland of the different investigated groups were used to measure sodium, potassium, chloride, and uric acid concentrations and contents respectively as follow:

i-Determination of sodium (Na) and potassium (K)

Colorimetric determination of serum and salt gland tissue homogenate sodium and potassium was achieved by using Teco Diagnostics Kits following the modified method of Knauff (19).

ii-Determination of chloride $(\mathrm{Cl})$

Chloride concentration and contents were measured by using Teco Diagnostics Kits.

\section{iii- Determination of uric acid}

Uric acid concentration and contents were measured by using Bioste- uric acid Kit.

3- Determination of serum aldosterone concentration

Serum aldosterone concentration was determined by using Dia Metra company kits following the competitive immunoenzymatic colorimetric method (20). The values of aldosterone concentrations were expressed in $\mathrm{pg} / \mathrm{mL}$.

\section{4- Measurements of Na-K-ATPase activity}

The procedure of the measurement was based on the determination of the inorganic phosphate liberated from the substrate ATP. Its activity (expressed as micromoles $\mathrm{pi} / \mathrm{mg}$ tissue/min) was calculated as the difference between the inorganic phosphate liberated in the presence and absence of potassium as described in details by El-Bakary (21).

\section{III- Statistical Analysis}

Statistical evaluation of the present data has been made by using one ways Anova test whereas the level of significance was estimated taking the probability $(\mathrm{p}<0.05)$ as a minimal requirement for significance. All the investigated parameters were presented as means \pm standard error.

\section{Results:}

In the current study, the salt-stressed and the wild migratory ducks promptly showed nasal gland secretion, its discharge came out through the nares and dripped off from the tip of the beak. While the control ducks showed no salt gland secretion.

\section{1- Body weight}

The data concerning the body weights of the different studied groups were presented in Figure (1). The mean initial body weight $(2.72 \pm 0.05 \mathbf{K g})$ of the control group of the female domestic ducks was closed to that of the saltstressed ones $(\mathbf{2 . 7 5} \pm \mathbf{0 . 0 5} \mathbf{~ K g})$. However, their mean body weights were significantly $(\mathrm{P}<0.001)$ heavier than the body weight $(1.11 \pm 0.03 \mathrm{Kg})$ of the female wild migratory ducks. The mean body weights of the salt-stressed domestic ducks after one week of salt manipulation ( $2.85 \pm 0.06 \mathrm{Kg}$ ) as well as at the end of the experiment (3.01 $\pm \quad 0.07 \quad \mathbf{K g})$ were significantly $(\mathrm{P}<0.001)$ heavier comparing to those of the corresponding control ones.

\section{II- Serum composition}

\section{i $\quad$-Serum electrolyte concentrations}

Serum sodium $(\mathrm{Na})$, potassium $(\mathrm{K})$, chloride $(\mathrm{Cl})$, uric acid $(\mathrm{U})$, and aldosterone concentrations of the different studied species were illustrated in Figures (2-6). Serum sodium concentrations of control $(\mathbf{1 4 2 . 0 \pm} \quad \mathbf{0 . 8} \mathrm{mmole} / \mathrm{L})$, saltstressed $(\mathbf{1 5 1 . 8} \pm \mathbf{0 . 8} \mathrm{mmole} / \mathrm{L})$, and wild migratory ducks $(\mathbf{1 7 5 . 9} \pm \mathbf{2 . 8} \mathrm{mmole} / \mathrm{L})$ respectively were obviously varied, with 
the salt-stressed group having higher serum sodium comparing to that of the control. However, the difference was insignificant ( $\mathrm{P}>0.05$ ). On the other hand, serum sodium of the wild migratory ducks was significantly $(\mathrm{P}<0.001)$ higher than those of both salt-stressed and control ducks.

In addition, serum potassium concentrations of all studied groups followed the same pattern as those of serum sodium concentrations, with the wild migratory ducks having the highest serum potassium $(\mathbf{5 . 9 2 \pm} \mathbf{0 . 9 5} \mathrm{mmole} / \mathrm{L})$ concentration followed by salt-stressed $(5.41 \pm 1.2 \mathrm{mmole} / \mathrm{L})$, then the control ducks which had the lowest serum potassium (4.36 $\pm \quad 0.9$ mmole/L) concentrations respectively.

For all the studied groups, serum chloride concentrations were distinctly varied, where the wild migratory ducks (5.2 \pm $1.3 \mathrm{mmole} / \mathrm{L}$ ) had the highest value

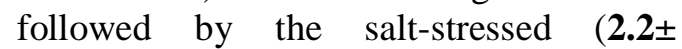

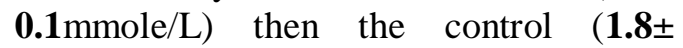
$\mathbf{0 . 0 1} \mathrm{mmole} / \mathrm{L}$ ) ones which showed the lowest concentrations respectively. The difference was highly significant $(\mathrm{P}<0.001)$ for wild ducks in comparison with those of both the salt-stressed and control ones. On the other side, the difference was insignificant $(\mathrm{P}>0.05)$ between the salt-stressed and the control ones.

On concerning serum uric acid concentrations, it was recorded that serum uric acid $(\mathbf{7 . 3} \pm 0.4 \mathrm{mg} / \mathrm{dl})$ concentration of the wild migratory ducks was obviously higher comparing to the respective values of the salt-stressed $(2.9 \pm \mathbf{0 . 2} \mathrm{mg} / \mathrm{dl})$ and the control ones $(\mathbf{2 . 2 \pm} \mathbf{0 . 1} \mathrm{mg} / \mathrm{dl})$ respectively. However, the differences were insignificant $(\mathrm{P}>0.05)$ for the saltstressed ducks when compared with the control ones, and highly significant $(\mathrm{P}<0.001)$ for the wild ducks in comparison with the respective values of both the salt-stressed and control groups.

\section{ii- Serum aldosterone concentration}

Referring serum aldosterone concentrations of the examined groups, it was observed that wild migratory ducks had significant $(\mathrm{P}<0.05)$ high serum aldosterone concentration (5341.9 \pm 820 $\mathrm{pg} / \mathrm{ml}$ ) in comparison with those of the control $(619.1 \pm 96.3 \mathrm{pg} / \mathrm{ml})$ and the saltstressed ducks (1110.1 $\pm 208.6 \mathrm{pg} / \mathrm{ml})$ respectively. However, serum aldosterone concentration of the salt-stressed ducks was insignificantly changed compared with that of the control ones.

III- Salt gland tissue homogenate composition

i-Salt gland tissue electrolyte contents

The salt gland homogenate tissue sodium $(\mathrm{Na})$, potassium $(\mathrm{K})$, chloride $(\mathrm{Cl})$ and uric acid contents of all the examined groups were demonstrated in Figures (2-5). Regarding the salt gland tissue sodium contents of the investigated avian species, the data revealed that the wild migratory ducks showed the highest value $(\mathbf{1 6 0 . 2} \pm \mathbf{2 . 1} \mathrm{mg} /$ wet $\mathrm{g})$, while the saltstressed ducks had moderate value $(\mathbf{1 4 6 . 0} \pm \mathbf{3 . 1} \mathrm{mg} /$ wet $\mathrm{g})$ followed by the control ones which showed the lowest value $(\mathbf{1 3 0 . 6} \pm \mathbf{1 . 7} \mathrm{mg} /$ wet $\mathrm{g})$ respectively. The differences were highly significant $(\mathrm{P}<0.001)$ for the wild migratory group comparing to the salt-stressed and the control ones.

In addition, salt gland tissue potassium contents of all the studied groups followed the same pattern as those of the sodium contents; the wild migratory ducks $(\mathbf{7 7 . 9} \pm \mathbf{0 . 4} \mathrm{mg} /$ wet $\mathrm{g})$ had the highest values followed by the salt-stressed ducks (52.4 $\pm \mathbf{0 . 6} \mathrm{mg} /$ wet $\mathrm{g}$ ) then the control group which had the lowest value $\mathbf{( 4 8 . 1 \pm 1 . 2} \mathrm{mg} /$ wet $\mathrm{g})$ respectively. However, the differences were insignificant $(\mathrm{P}>0.05)$ for salt-stressed ducks in comparison with control ones and highly significant $(\mathrm{P}<0.001)$ for wild ducks comparing to those data of both saltstressed and control ducks.

Moreover, the salt gland tissue chloride contents of all the investigated avian groups followed typically the same pattern as those of both sodium and potassium contents. The recorded results dealing with salt gland tissue chloride contents were $(\mathbf{1 2 . 0} \pm \mathbf{1 . 0} \mathrm{mg} /$ wet $\mathrm{g})$, $(5.5 \pm 0.3 \mathrm{mg} /$ wet $\mathrm{g})$, and $(\mathbf{4 . 9 \pm 0 . 1} \mathrm{mg} /$ wet g) for the wild migratory, the salt-stressed and the control ducks respectively.

Furthermore, the data considering uric acid contents of all selected avian species exhibited the same pattern as those of the sodium, potassium and chloride contents; 
with the wild migratory ducks had highly significant $(\mathrm{P}<0.001)$ higher values $(13.9 \pm 1.4 \mathrm{mg} /$ wet $\mathrm{g})$ than the salt-stressed ducks (5.3 $\pm \mathbf{0 . 5})$ and the control ones $(\mathbf{2 . 7} \pm \mathbf{0 . 1})$ respectively.

\section{ii-Salt gland tissue Na-K-ATPase activity}

The activity of Na-K-ATPase of the salt gland homogenates of the studied groups was presented in Figure (7). The activity of the enzyme exhibited variable pattern among the different examined avian groups, with the salt-stressed ducks showed significantly $(\mathrm{P}<0.001)$ higher value $(\mathbf{2 5} \pm \mathbf{1} \mu \mathrm{mole} \mathrm{pi} / \mathrm{mg}$ tissue $/ \mathrm{min})$ in comparison to both wild migratory (18 $\mathbf{1}$ $\mu$ mole $\mathrm{pi} / \mathrm{mg}$ tissue/min) and control (12 $\mathbf{0 . 0 3} \mu \mathrm{mole} \mathrm{pi} / \mathrm{mg}$ tissue/min) groups respectively.

\section{Discussion:}

Fluid and ion homeostasis in birds involve several organ systems including the kidneys, cloaca, ceca and the nasal salt glands (22). Excess salt loads in most nonmammalian vertebrates are dealt with a variety of extra-renal salt-secreting structures collectively described as salt glands.

The best studied of these glands are the supra-orbital salt glands of birds. They have a mechanism of concentrated salt ions from the blood and work in conjunction with the kidneys. Such glands allow marine birds to maintain water and ion concentration balance by excreting salt from seawater they ingest with their food. The concentrating ability of salt can reach from five to eight times (8).

Many terrestrial non-marine birds have functional salt glands $(16,23)$. Their salt glands are usually quiescent. However, such glands show remarkable levels of phenotypic plasticity both morphological and physiological as a consequence of drinking saline water $(16,24)$.

Two distinct types of response to osmoregulatory disturbances are shown by the avian salt glands: a progressive adaptive response on initial exposure to a salt load that results in the induction and enhancement of the secretory performance or capabilities of the gland; and the rapid activation of existing osmoregulatory mechanisms in the adapted gland in response to immediate osmoregulatory imbalance (24).

In the present study, the initial body weights of the control and salt- stressed female domestic ducks are approximately very close to each other. However, their final body weights followed different pattern; with salt-stressed group having significantly heavier body weight compared to the control ones. While the body weight of the wild ducks is markedly lighter when compared to both control and salt-stressed ducks. Such observation reflected that the osmotic-stressed ducks gain more weight in comparison with the control ones. Thus, the salt-stressed ducks have low tolerance to saline conditions, since they did not able to maintain body weight while drinking salt water. Similar results have been recorded by Hughes (25) and El Gohary (16) on experimentally saltstressed adult Mallard ducks and domestic geese respectively. In contrast, Hannam et al. (26) mentioned that high salinity resulted in significant body weight loss of $4.4 \mathrm{~g}$ by day 3 and dehydration.

It has been well established that osmotic salt $(\mathrm{NaCl})$ stress stimulated avian salt gland (24). However, the degree of stimulation is depended upon the level of the salinity of the drinking water to which the bird is exposed (27). When the bird drinks high salt water, sodium enters the plasma from the gut and plasma osmolality (Osmpl) increases. This induces water to move out cells expanding the extracellular fluid volume (ECFV) (28).

In the present work, increasing concentrations of serum sodium and potassium in the salt-stressed ducks as well as wild migratory ones in comparison with the control birds may be due to the increase of water consumption containing the high level of $\mathrm{NaCl}$ which caused apparent increase in the blood sodium and potassium concentrations and consequently, due to stress on kidney functions.

In addition, salt gland homogenate sodium and potassium contents followed the same pattern as those of serum concentrations; wild ducks showed the highest value followed by the salt-stressed ones then the control which showed the lowest value. These results are in agreement with those 
obtained by El-Badry (6) and El Gohary (16) who found a highly significant increase of the blood sodium and potassium concentrations accomplished with increasing water salinity due to increasing retention of salt and water in both intracellular and extracellular fluid compartments.

In the current investigation, serum chloride concentrations of both the salt-stressed ducks as well as wild migratory ones were obviously higher when compared with that of the control ones. Such results are in agreement with the findings of Roberts \& Hughes (28) who reported that saline acclimation increased the plasma sodium and chloride concentrations of ducks and gulls. In addition, chloride contents of the salt gland tissue homogenate of the different studied groups followed the same pattern of the serum chloride concentrations. However, there is no available data concerning chloride content of the salt gland tissue homogenate to compare with.

In the present study, serum uric acid concentrations were markedly different among experimental birds; the wild migratory ducks showed the highest level followed by the salt-stressed ducks then the control ones. The recorded data go parallel with the findings of El-Badry et al.(6) who recorded an elevation in plasma creatinine and uric acid of ostrich subsequent to saline drinking water. Elevation in serum uric acid may be attributed to a reduction of glomerular filtration rate (GFR), since the serum concentration of uric acid depends largely on GFR as been mentioned by Gavin (29).

The present data showed an elevated serum aldosterone in salt-stressed as well as wild migrated group when compared with the control. Such findings are consistent with the work of Sturkie (30) who mentioned that drinking salt water in birds stimulate hypothalamo-hypophyseal adrenal system, where adrenocortictrophic hormone $(\mathrm{ACTH})$ is released from anterior pituitary and triggers the secretion of both aldosteron and corticosterone from adrenal cortex. This explains the increase of aldosterone level in bird serum.
Further confirmation of the recorded data comes from the study of Hughes (25) and El-Badry et al. (6) who reported that birds drink high saline water recorded higher levels of aldosteron than the control group. The level of the hormone was significantly increased with increasing saline water level.

Salt glands are typified by their abundance of ion pumps, including $\mathrm{Na}+\mathrm{K}+$-ATPase (NKA), a basolateral, transmembrane ion pump responsible for the maintenance of cellular electrochemical gradients through the movement of $\mathrm{Na}+$ and $\mathrm{K}+$ ions against their osmotic gradients. NKA is consistently present in large amounts in salt gland tissues specialized for active ion transport (31). Therefore, it is well established that the avian salt glands are extraordinary structures for studying the functional relationship between $\left(\mathrm{Na}^{+}-\mathrm{K}^{+}\right)$ATPase and active transport on the level of the whole organ. The salt gland provides an additional advantage in such study because its primary and perhaps only function is the concentration and secretion of electrolytes. Na-K-activated ATPase enzyme is associated with the extensive inflodings of the salt gland secreting cells (32).

In the present work, the recorded elevation in the activity of salt gland Na-K-ATPase in the salt-stressed ducks compared to both control and wild migratory ducks is in agreement with the findings of Hildebrandt (33) and El Gohary (16). They mentioned that chronic salt stress in different avian species caused an adaptive increases in the activity of the $\mathrm{Na}+\mathrm{K}+-$ ATPase. Similar changes in Na-K-ATPase activity and expression have also been observed in elasmobranch and teleost models (34,35).

In addition, the data concerning the increment of glandular (Na+-K+)-ATPase activity in response to osmotic stress in the present work is consistent with an elevation in Na-K-ATPase content in the principal cell of the salt gland during saltwater adaptation in ducks as been reported by Sarras et al. (36).

Moreover, the recorded elevation of Na-KATPase activity in the salt-stressed ducks as well as migrated ones in comparison 
with the control may be attributed to the high level of aldosterone which increase the passive entry of sodium across the luminal membrane as been suggested by Petty et al. (37). Support for such suggestion comes from the observations of Hughes (25) who stated that during exposure to saline, marine birds maintain elevated aldosterone levels despite high $\mathrm{Na}$ intake.

When the organisms subjected to environmental stress, the regulation of gene expression in effector organs is crucial for the initiation of adaptive growth and differentiation processes that serve to optimize organ function and to enable the animal to maintain its homeostasis.

Therefore, in the present work it can be concluded that the recorded elevated $\mathrm{Na}$ K-ATPase activity and serum aldosterone concentrations may be resulted in a much higher efficiency of salt secretion of the salt gland in salt-stressed ducks to maintain water and electrolyte balance of the body fluid regardless the high salt manipulation.

References:

1- Schmidt-Nielsen K (1960). The saltsecreting gland of marine birds. Circulation., 21:955 -967.

2- Müller C, Hildebrandt JP (2003). Salt glands- the perfect way to get rid of too much sodium chloride. Biologist, 50: 255-258.

3- Müller C, Sendler M. ,Hildebrandt JP (2006). Down regulation of aquaporins 1 and 5 in nasal gland by osmotic stress in ducklings, Anas platyrhynchos: implications for the production of hypertonic fluid. J. Exp. Biol., 209: 40674076.

4- Bennett DC, Hughes RM ( 2003). Comparison of renal and salt gland function in three species of wild ducks. J. Exp. Biol., 206: 3273-3284.

5- Hughes MR, Kitamura N, Bennett DC, Gray DA, Sharp PJ, Poon AM (2007). Effect of melatonin on salt gland and kidney function of gulls, Larus glaucescence. Gen. Comp. Endocrinol., 151: 300-307.

6- El- Badry ASO, Ali AA, Ali W AA, Ahmed MA (2011). The role of nasal gland and vitamin $\mathrm{c}$ in alleviate the adverse effects of osmotic stress on ostrich. Egy. Poult. Sci., 31: 233-247.

7- Haley D (1984). Seabirds of Eastern North Pacific and Arctic Waters, Seattle. Washington: Pacific Search Press, p22.

8- Sabat P, Farina JM, Gamboa MS (2003). Terrestrial birds living on marine environments: Does dietry composition of Cinclodes nigrofumosus (Passeriformes: Furnariidae) predict their osmotic load? Rev. Chil. Hist. Nat., 76: 335-343.

9- Nagy KA, Peterson CC (1988). Scaling of water flux rate in animals. Univ. Calif. Publ. Zool., 120.

10- Bennett DC, Gray DA, Hughes MR (2003). Effect of saline intake on water flux and osmotic homeostasis in Pekin ducks (Anas platyrhynchos). J. Comp. Physiol., 173: 27 -36.

11- Almansour MI (2007). Anatomy, histology and histochemistry of the salt glands of the greater flamingo Phoenicopterus rubber roseus (Aves,Phoenicopteridae). Saudi J. Biol. Sci., 14: 137-144.

12- El Gohary ZMA, El-Sayad FI, Ramadan MM (2009).Comparative studies on the structural organization of the salt glands of two different avian species.Egypt. J. Zool., 53: 18-22.

13- Simon E (1981). Effects of CNS temperature on generation and transmission of temperature signals in homeotherms. A common concept for mammalian and avian thermoregulation. Pflügers. Arch., 392: 79-88.

14- Dunson WA, Dunson MK, Ohmart RD (1976). Evidence for the presence of nasal salt glands in the roadrunner and the coturnix quail. J. Exp. Zool., 198: 209216.

15- Merchant JL, Papermaster DS, Barrnett RJ (1985). Correlation of $\mathrm{Na}+, \mathrm{K}+-\mathrm{ATPa} e$ content and plasma membrane surface area in adapted and deadapted salt glands of ducklings. J. Cell Sci.., 78: 233-246.

16- El Gohary ZMA (2009). Anatomica 1 and functional alterations of the goose salt gland subjected to sodium chloride. J.Egypt.Ger.Soc.Zool.,58:65-78.

17- Holmes WN, Fletcher GL, Stewart DJ (1968). The patterns of renal electrolyte excretion in the duck (Anas platyrhynchos) maintained on freshwater 
and on hypertonic saline. J. Exp. Biol., 45: 487-508.

18- Hughes MR, Roberts JR, Thomas BR (1989). Renal function in freshwater and chronically saline-stressed male and female Pekin ducks. Poult. Sci., 68: 408 416.

19- Knauff RE (1968). Sodiumpotassium measurement interferences in various biological fluids. Clin. Chimica. Acta., 20: 135-138.

20- Schwartz F, Hadas E, Harnik M, Solomon B (1990). Enzyme-linked immunosorbent assays for determination of plasma aldosterone using highly specific polyclonal antibodies . J. Immun. Chem., 234: 215-234.

21- El-Bakary NS (2000).Comprative studies on the anatomical and functional adaptation of vertebrate's kidneys in relation to the nature of the habitat. M.Sc.Thesis, Damiette Fac. of sci., Mansoura Univ.

22- Braun J (1999). Integration of organ systems in avian osmoregulation. J. Exp. Zool., 28: 702-707.

23- Sabat $P$ (2000). Birds in marine and saline environments : living in dry habitats. Rev. Chil. Hist. Nat., 73: 401410.

24- Shuttleworth TJ, Hildebrandt JP (1999). Vertebrate salt glands: short- and long-term regulation of function. J. Exp. Zool., 283 : 689-701.

25- Hughes MR (2003). Regulation of salt gland, gut and kidney interactions.Comp. Biochem. Physiol., 136: 507-524.

26- Hannam KM, Oring LW, Herzog MP (2002). Impacts of salinity on growth and behavior of American avocet chicks. Waterbird Society., 26: 119-125.

27- Hildebrandt JP (2002). Coping with excess salt : adaptive functions of extrarenal osmoregulatory organs in vertebrate. Zool., 104: 209-220.

28- Roberts JR, Hughes MR (1984). Exchangeable sodium pool size and sodium turnover in freshwater- and saltwater-acclimated ducks and gulls. Can. J. Zool., 62: 2142-2145.

29- Gavin JB (1995). Assessment of renal function. The Md. GR. J., 23: 102105.

30- Sturkie PD (1976). Kidneys, extrarenal salt excretion, and urine. In: "Avian Physiology" Springer-Verlag, New York, 264-285.

31- Dunson MK, Dunson WA (1975). Relation between plasma Na concentration and salt gland Na-K ATPase content in diamondback terrapin and yellow-bellied sea snake. J. Comp. Physiol., 101: 89-97.

32- Schmidt-Nielsen B (1976). Intracellular concentrations of the salt gland of the herring gull Larus argentatus . Am. J. Physiol.., 230: 514-552.

33- Hildebrandt JP (1997). Changes in $\mathrm{Na}+\mathrm{K}+$-ATPase expression during adaptive cell differentiation in avian nasal salt gland. J .Exp. Biol., 200: 1895-1904.

34- Pillans RD, Good JP, Anderson WG, Hazon N, Franklin CE (2005). Freshwater to seawater acclimation of juvenile bull sharks (Carcharhinus leucas): plasma osmolytes and $\mathrm{Na}(+) / \mathrm{K}(+)$-ATPase activity in gill, rectal gland, kidney and intestine. J. Comp. Physiol., 175: 37- 44.

35- Evans DH (2008). Teleost fish osmoregulation: what have we learned since August Krogh, Homer Smith and Ancel Keys. Am. J. Physiol., 295: 704713.

36- Sarras MP, Rosenzweig LJ, Addis JS, Hossler FE (1985). Plasma membrane biogenesis in the avian salt gland: A biochemical and quantitative electron microscopic autoradiographic study. Am. J. Anat., 174: 45-60.

37- Petty KJ, Kokko JP, Marver D (1981). Secondary effect of aldosterone on Na-K ATPase activity in the rabbit cortical collecting tubule . J. Clin. Invest., 68: 1514-1521. 
Zeinab El-Gohary et al

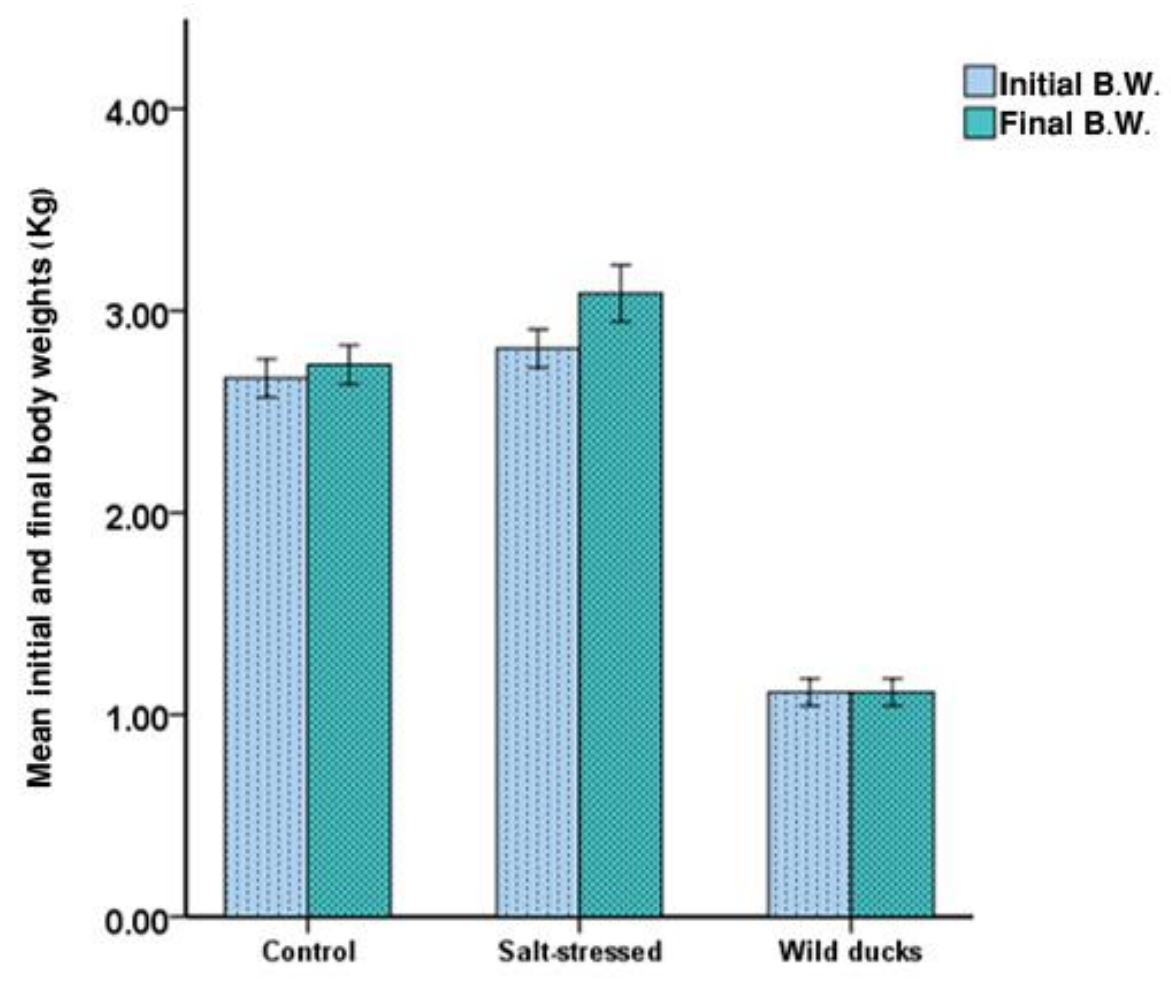

Fig.(1): Initial and final body weights (Kg) of the control, salt-stressed female domestic ducks (Anas platyrhyncha) and the wild migratory female ducks (Anas clypeata). $\{$ bars $=$ SE $\}$ 


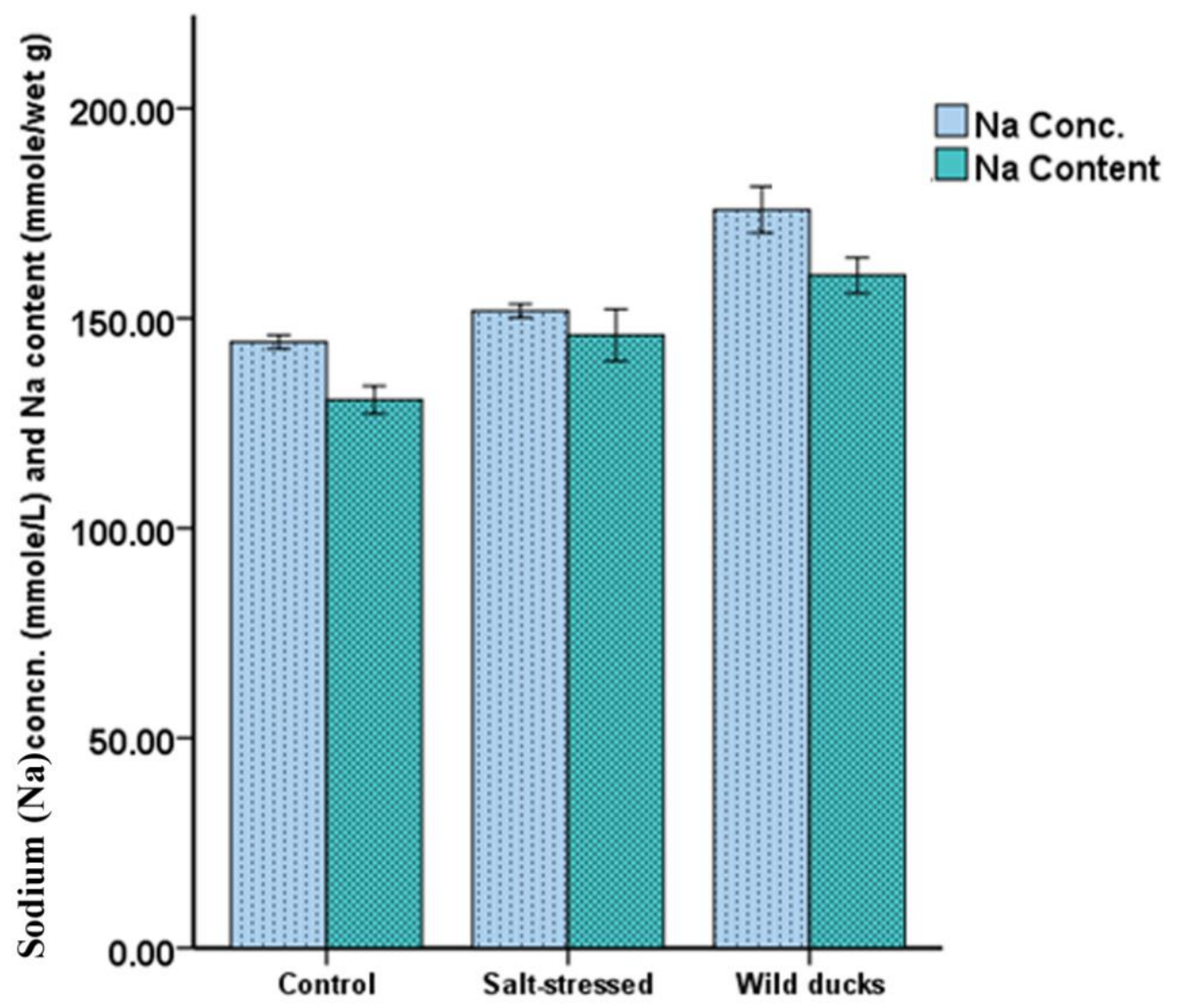

Fig.(2): Serum concentrations (mmole/L) and tissue contents (mmole/wet g) of sodium (Na) of the control, salt-stressed female domestic ducks (Anas platyrhyncha) and the wild migratory female ducks (Anas clypeata). $\{$ bars $=\mathrm{SE}\}$ 


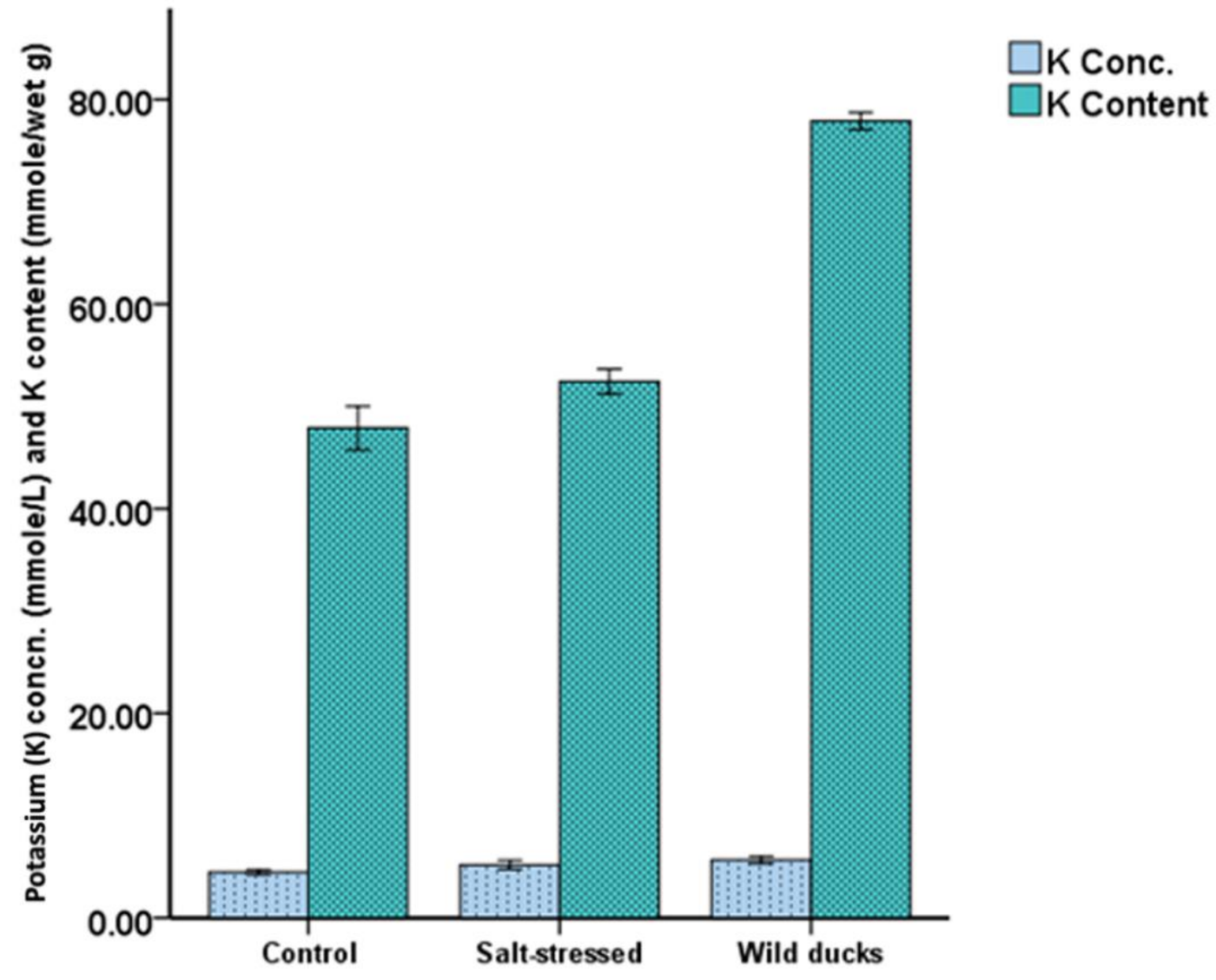

Fig.(3): Serum concentrations (mmole/L) and tissue contents (mmole/wet g) of potassium (K) of the control, salt-stressed female domestic ducks (Anas platyrhyncha) 
and the wild migratory female ducks (Anas clypeata).$\{\mathrm{bars}=\mathrm{SE}\}$

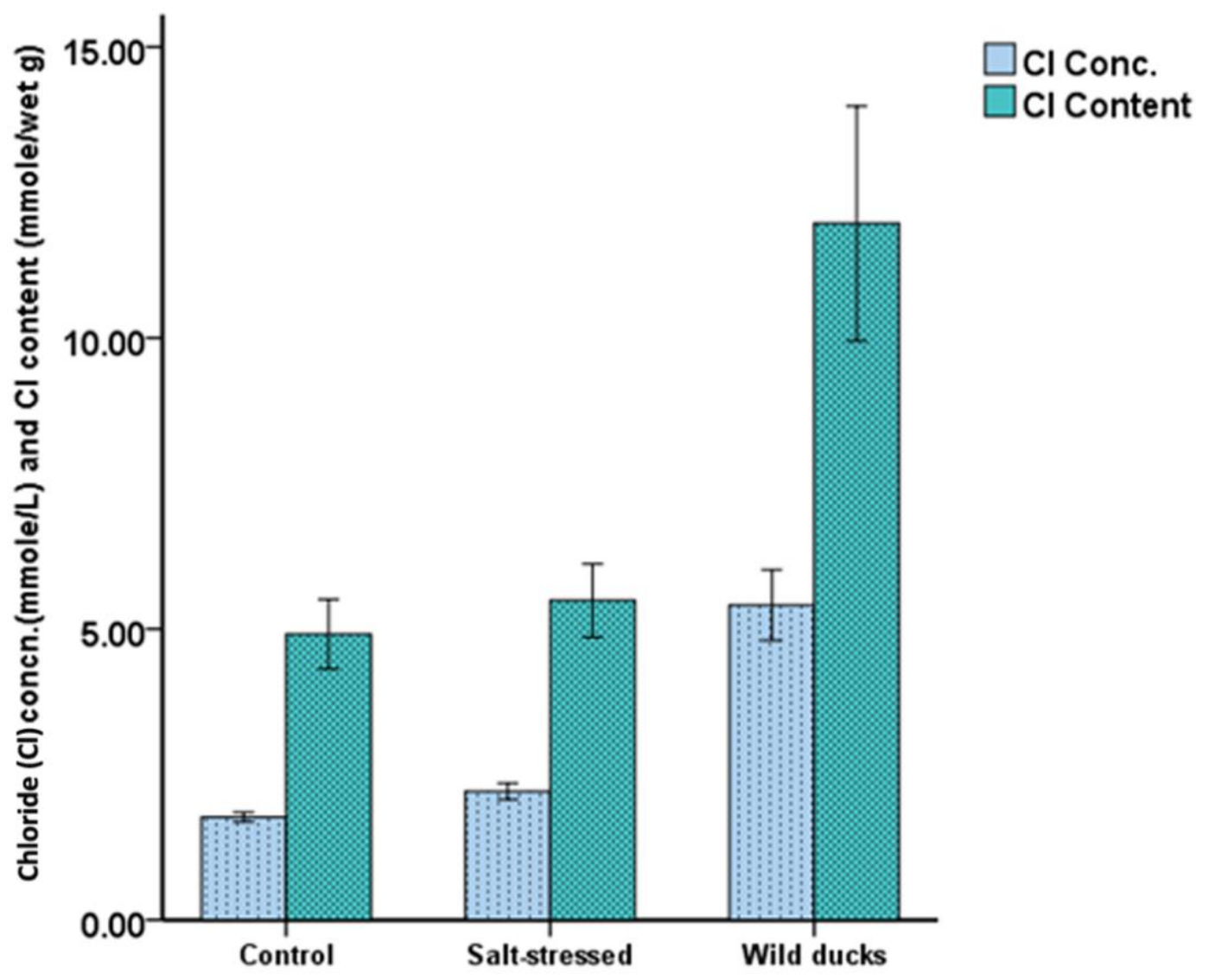

Fig.(4): Serum concentrations (mmole/L) and tissue contents (mmole/wet g) of chloride (CI) of the control, salt-stressed female domestic ducks (Anas platyrhyncha) and the wild migratory female ducks (Anas clypeata). $\{$ bars $=\mathrm{SE}\}$ 


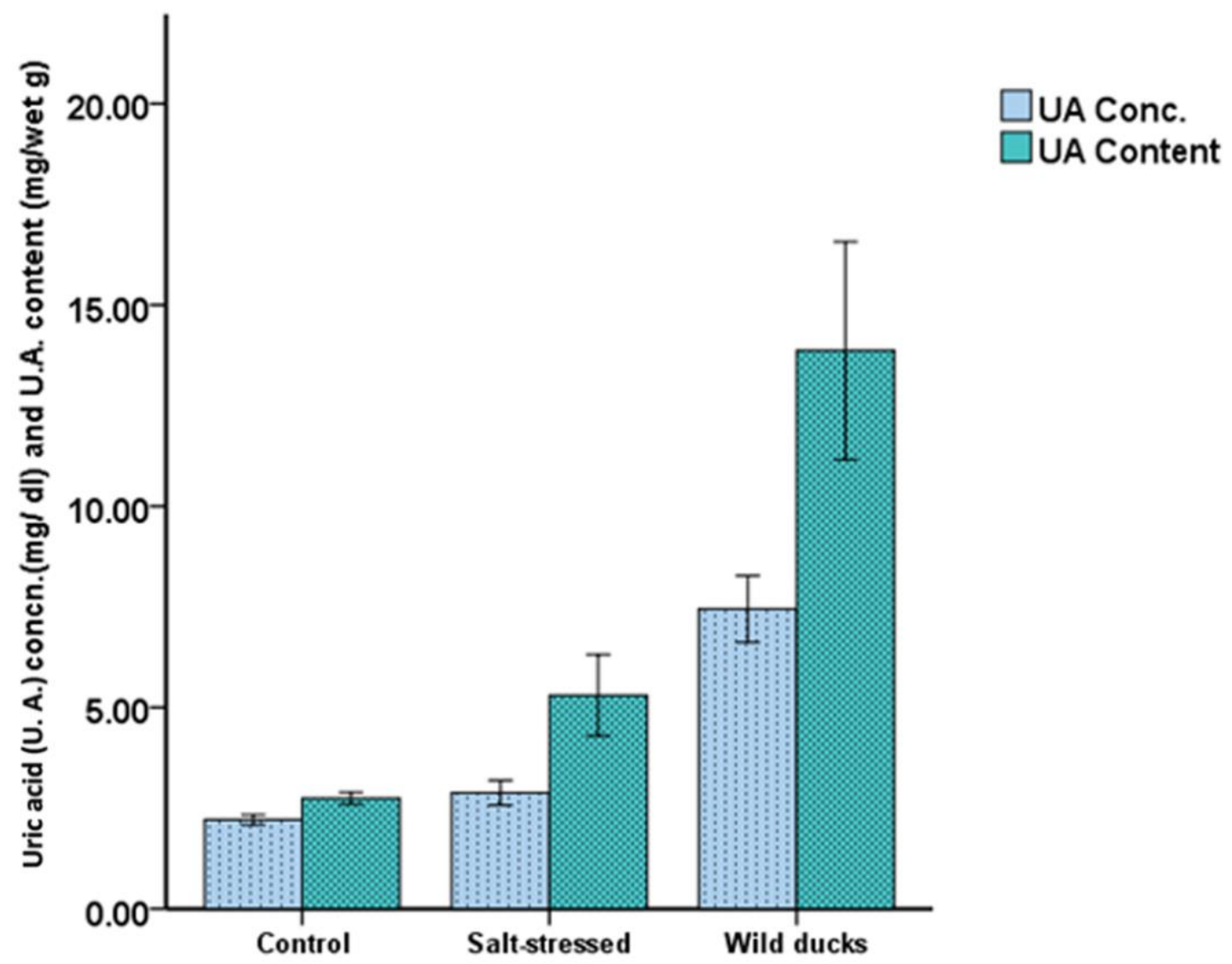

Fig.(5). Serum concentrations (mg/dl) and tissue contents (mg/wet g) of uric acid (U.A.) of the control, salt-stressed female domestic ducks (Anas platyrhyncha) and the wild migratory female ducks (Anas clypeata).. $\{$ bars=SE $\}$ 


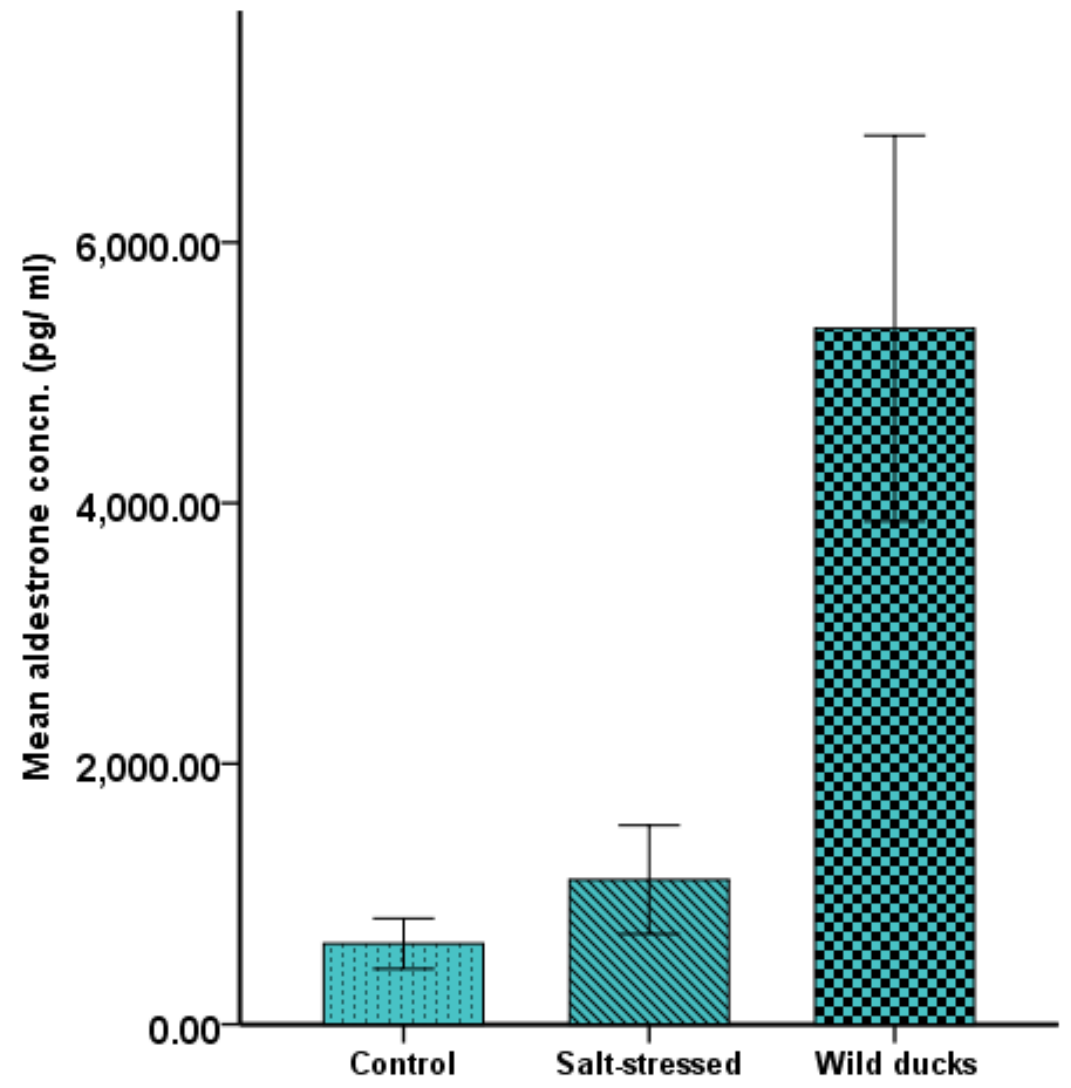

Fig. (6): Serum aldosterone concentrations $(\mathrm{pg} / \mathrm{ml})$ of the control, salt-stressed female domestic ducks (Anas platyrhyncha) and the wild migratory female ducks (Anas clypeata $).\{$ bars $=\mathrm{SE}\}$ 


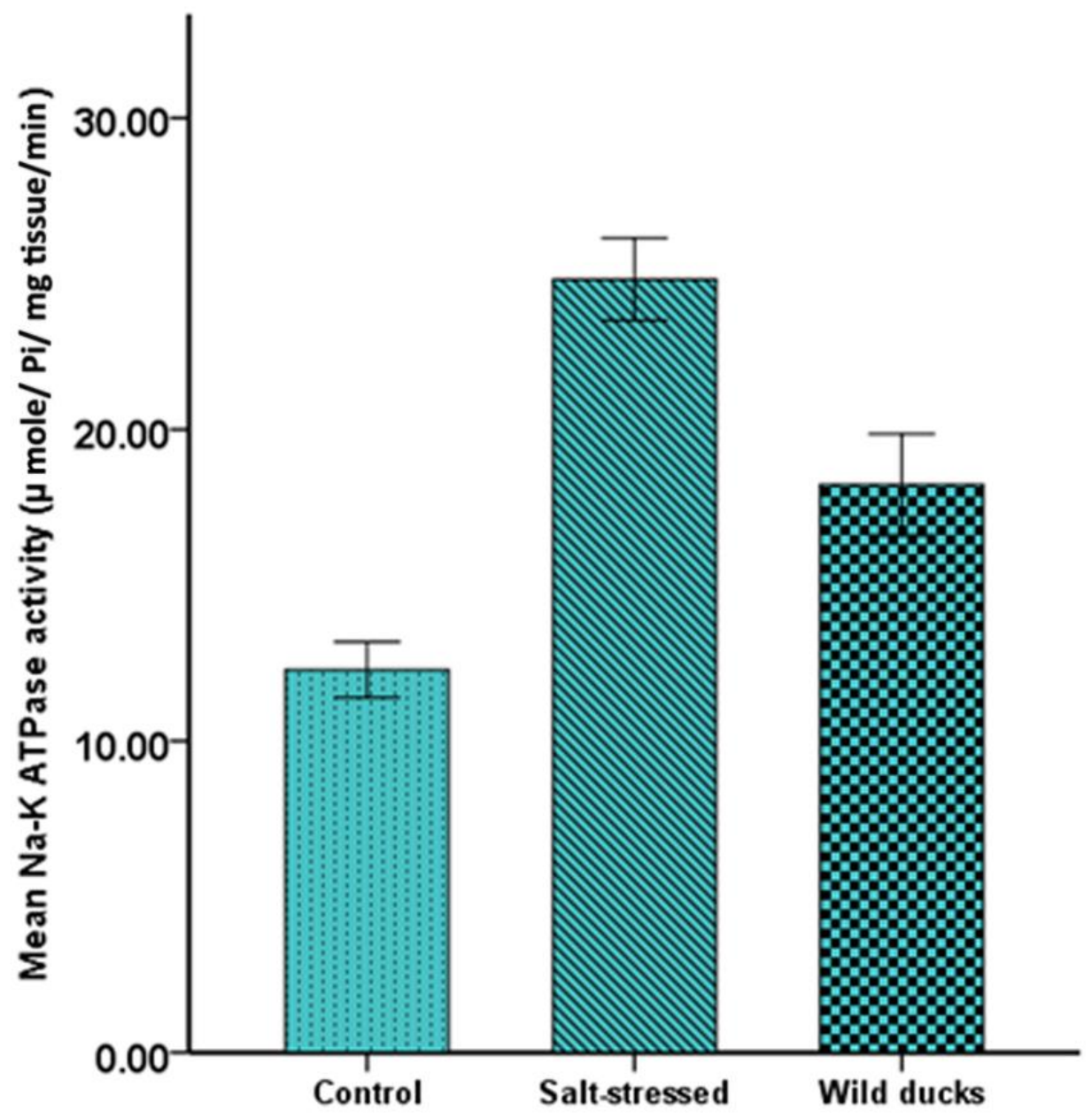

Fig.(7): Na-K ATPase activity of the right medial segment tissue homogenate of the salt glands of the control, salt-stressed female domestic ducks (Anas platyrhyncha) and the wild migratory female ducks (Anas clypeata). $\{$ bars=SE $\}$ 